\title{
PHARMINE Report \\ The PHARMINE study on the impact of the European Union directive on sectoral professions and of the Bologna declaration on pharmacy education in Europe
}

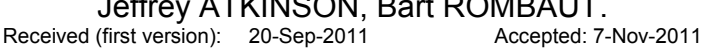

\begin{abstract}
${ }^{\star}$
The Bologna declaration and the European Union (EU) directive 2005/36/EC on the recognition of professional qualifications influence the mobility of pharmacy students and pharmacy professionals, respectively. In addition the Bologna declaration aims at tuning higher education degrees including pharmacy throughout the EU in order to prepare for a harmonised European Higher Education Area. The directive outlines the knowledge, skills and qualifications required for the pursuit of the professional activity of a pharmacy in the EU. The PHARMINE project (Pharmacy Education in Europe, www.pharmine.org) looked at how the Bologna declaration and the directive influence modern-day pharmacy education and training in Europe.
\end{abstract}

Keywords: Education, Pharmacy. International Educational Exchange. European Union. Europe.

\footnotetext{
`Jeffrey ATKINSON. Executive Director, Pharmacolor Consultants Nancy. Villers, (France).

Bart ROMBAUT. President, European Association of Faculties of Pharmacy. Department of Pharmaceutical Biotechnology and Molecular Biology, Faculty of Medicine and Pharmacy, Vrije Universiteit Brussels. Brussels, (Belgium).
}

\author{
ESTUDIO PHARMINE SOBRE EL IMPACTO \\ DE LA DIRECTIVA EU SOBRE \\ PROFESIONES SECTORIALES Y DE LA \\ DECLARACIÓN DE BOLOÑA EN LA \\ EDUCACIÓN EN FARMACIA EN EUROPA
}

\section{RESUMEN}

La Declaración de Boloña y la Directiva de la Unión Europea (UE) 2005/36/EC sobre reconocimiento de cualificaciones profesionales influencian la movilidad de los estudiantes de Farmacia y de los profesionales farmacéuticos, respectivamente. Además, la Declaración de Boloña trata de sintonizar los grados de educación superior, incluyendo el de farmacia, en toda la UE para crear un Espacio Común de Educación Superior Europeo. La Directiva señala los conocimientos, habilidades y cualificaciones requeridos para el ejercicio profesional de la farmacia en la UE. El proyecto PHARMINE (Pharmacy Education in Europe,

www.pharmine.org) revise como la Declaración de Boloña y la Directiva influencian la educación y la formación modernas de la farmacia en Europa.

Palabras clave: Educación en Farmacia. Intercambio Educacional Internacional. Unión Europea. Europa.

\section{INTRODUCTION}

Within the European Union (EU), the sectoral profession of pharmacy (like medicine and dentistry) is governed by EU directive 2005/36/EC of the European parliament and of the council on the recognition of professional qualifications. The purpose of this directive is to streamline legislation on cross-border provision of services and automatic recognition of qualifications. The latter aims at ensuring free movement of professionals (pharmacists and others) within the 27 member states of the EU. The directive assigns the principal conditions for access to the activities in the field of pharmacy; articles 44 and 45 and annex 5.6.1 fix many aspects of pharmacy education and training (annex 1).

Pharmacy education is also influenced by the Bologna declaration. Here the aims are different. Whilst the directive 2005/36/EC defines the legal conditions for the recognition of professional 
qualifications within the 27 member states of the $\mathrm{EU}$, the Bologna declaration - taken up by the ministers of education and /or research from the 27 member states and the EU's 28 neighbouring countries - proposes actions for tuning courses in higher education institutions (HEls). The aim is to converge to an EU model of education, the European Higher Education Area (EHEA) (see annex 2).

The PHARMINE consortium consists of universities from EU member states and neighbouring countries that are members of the European Association of Faculties of Pharmacy (EAFP). The consortium surveyed pharmacies and pharmacists and looked at how EU higher education institutions and courses are organised. Furthermore PHARMINE evaluated how the EU directive and the Bologna declaration influence pharmacy education.

The PHARMINE consortium (see list at the end) produced country profiles with extensive information for each country, available at: http://www.pharmine.org/losse paginas/Country Pr ofiles/

\section{Comparable degrees and diploma supplement}

The first action of the Bologna declaration proposes the adoption of comparable degrees with implementation of a diploma supplement. As many aspects of the pharmacy course are fixed by articles 44 and 45 and annex 5.6.1 of the directive, courses in different countries are comparable.

The PHARMINE study showed that in most countries the sectoral profession model of pharmacy education based on directive 2005/36/EC consists of an integrated 5-year, seamless course (figure 1, left). The course has three main elements. The first element is that of generic knowledge (anatomy, physiology, general chemistry, physics, mathematics, etc.) and skills (communication, management, accounting, ethics, languages, etc.). Courses concentrate on such subjects during the early years - the time and effort spent on them dwindle towards the end of the five years' formation. The second element concerns pharmacy-specific knowledge and skills (pharmaceutical chemistry, drug formulation, pharmacology, toxicology, therapeutics, pharmaceutical care, legislation on dispensation of medicines, drug development and licensing, etc.). These pharmacy-specific competences are introduced early in the course in order to inculcate future professionals with the importance of pharmacy in the healthcare system; the time and effort spent on them progressively increase through the course. The third element is traineeship - an essential part of education and training in any sectoral profession - that is introduced early in the course and again gathers importance towards the end.

All HEls questioned (see list at the end) followed the above scheme and taught a curriculum based on the subjects listed in annex 5.6.1 of the directive. Several suggested that subjects such as biotechnology, immunology, pharmaceutical care, and marketing and management be included in the list.

The diploma supplement has eight sections of information identifying the holder of the qualification; the qualification, its level and function; the contents and results gained; certification of the supplement; details of the national higher education system plus any additional information. The supplement is designed as an aid to help recognition - it is not a $\mathrm{CV}$ or a substitute for the original qualification. Most pharmacy HEls questioned do not issue diploma supplements as yet.

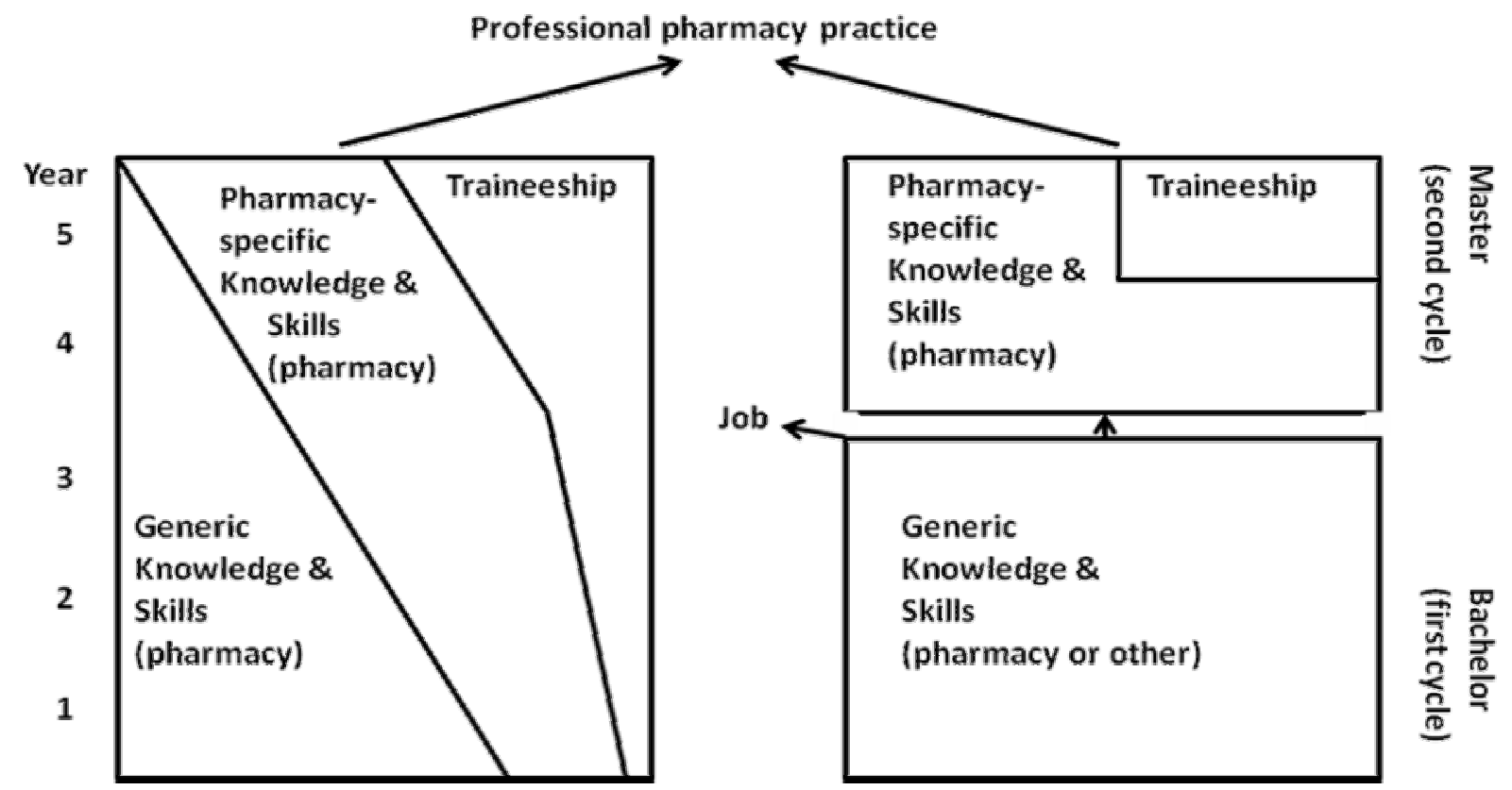

Figure 1. Models for pharmacy education and training in the EU based on the professional recognition directive (left) and the Bologna declaration (right). 


\section{Course length and structure}

The second action of the Bologna declaration concerns the global adoption in courses of a system based on two main cycles: an undergraduate/first cycle (bachelor, three years), followed by the postgraduate/second cycle (master, two years). The bachelor degree should "...be relevant to the European labour market as an appropriate level of qualification". Thus the Bologna model (figure 1, right) has two independent cycles or tiers with the same total duration of 5 years.

The emphasis is on improved mobility: mobility concerning entry into the job market with a bachelor degree, mobility amongst different disciplines with entry into a master program of students with a variety of different bachelor degrees, and finally mobility within the European Higher Education Area (EHEA, see annex) following harmonisation of courses into a bachelor-master system.

The Bologna model for pharmacy education if applied in strict concordance with the Bologna declaration would presumably differ from the model based on the directive in several ways. The bachelor course would have to be constructed such that it prepares graduates for continuation in the master program and also for entry into the job market. The master course would have to be constructed - for example with traineeship concentrated into the 4th or 5th year - to accommodate bachelor graduates from disciplines other than pharmacy.

Most (25/29) European countries do not apply the second action of Bologna and have a five-year integrated, seamless course in accordance with the directive. This is also true for candidate countries such as Iceland, Macedonia and Turkey.

Some countries such as Belgium, Sweden and Latvia award "academic" bachelor degrees that are a requirement for entrance into the master degree in pharmacy but not a qualification for the job market.

Finland produces bachelor graduates in pharmacy (B. Pharm.) that enter the job market with tasks similar to pharmacists in the areas of customer service and patient counselling. Such bachelors are however, excluded from pharmacy ownership, management and / or in-depth scientific issues. The position of responsible pharmacist is restricted to Master in Pharmacy graduates.

Germany has a 2+2+1 years structure with a "Staatsexamen" at the end of the second, fourth and fifth years.

Austria has a 4.5 year course and the UK a 4 year course.

\section{European Credit Transfer System credits ECTS and links to continuing professional development (CPD)}

The third Bologna action concerns ECTS, a system whereby students validate a period of instruction or training at a given $\mathrm{HEI}$ (annex 2). If the student then moves to another $\mathrm{HEI}$ in another discipline or another country, then this HEI has to accept the ECTS already accumulated. ECTS are designed to allow accumulation of learning experiences from different sources and transfer of learning experiences from different HEls and from different courses. For this $\mathrm{HEl}$ courses are organized into teaching units within semesters. Each teaching unit is validated by acquirement of a number of ECTS units.

The use of ECTS is based on the convention that 60 credits represent the workload of a full-time student during one academic year. Workload refers to the notional time an average learner might take to complete the required learning outcomes.

Almost all countries have introduced ECTS. Latvia has a separate system that is linked to ECTS as is the "English Credit Framework" used in the UK.

A second aspect of ECTS concerns their use at both pre- and postgraduate levels thus linking initial education to CPD. This was not observed in pharmacy HEls as most countries - excepting Hungary, Portugal and Romania - do not subject licence renewal to obligatory CPD.

\section{Obstacles to mobility}

The fourth action of the Bologna declaration focuses on removal of obstacles to student and staff mobility.

Budget and lodgings were identified as obstacles and many countries have provided means to overcome them. Language was also cited as an obstacle by most; some countries overcome this by teaching courses in English, such as Malta where the entire degree course is given in English.

Another obstacle was the integrated and rigid nature of the course structure that hindered student exchange programs of less than one year. Countries such as Denmark overcome this by focusing student exchange in the last years of the program (master level) during which the course organisation is much less rigid.

\section{European quality assurance system}

The fifth Bologna action concerns promotion of European cooperation in quality assurance. Most countries questioned had national quality assurance agencies that were however often members of the European Association for Quality Assurance in Higher Education (ENQA). ENQA disseminates information on good practices in the field of quality assurance in higher education to European quality assurance agencies and higher education institutions (http://www.enqa.eu/). National quality assurance agencies also called on international experts.

\section{European dimension in education}

The sixth Bologna action concerns the promotion of a European dimension in education. Most countries have inter-institutional cooperation with regard to curricular development and integrated programmes 
but these are introduced late in the course or even at the postgraduate level and are focused on science and research. Many are not limited to pharmacy but include other disciplines for example course in preclinical and clinical drug evaluation.

\section{Mobility of pharmacy students}

In the PHARMINE study, data were obtained on student mobility. Mobility (\%) was calculated as follows: (( (number of incoming + outgoing students per year) $x$ months) / (total student number $\times 9$ months)) $\times 100$. Average mobility for students was $3.5 \pm 3.3$ and for staff $0.4 \pm 0.4$. Thus mobility was low in both cases and there was wide variability amongst HEls.

\section{Summary}

The PHARMINE study revealed that the main factor acting on the structure and contest of the curriculum for pharmacy was the directive. Pharmacy HEls do incorporate some Bologna actions such as the use of ECTS but other actions such as the bachelormaster structure are more difficult to implement.

\section{ACKNOWLEDGEMENTS}

The authors thank the following members of the PHARMINE ("PHARMacy Education IN Europe") consortium:

C. NOE, University of Vienna, AUSTRIA.

B. ROMBAUT, H. HALEWIJCK and B. THYS, Vrije Universiteit Brussel, Faculty of Medicine and Pharmacy, Dept. Pharmaceutical Biotechnology and Molecular Biology, BELGIUM

V. PETKOVA and S. NIKOLOV, University of Sofia, Faculty of Pharmacy; V. BELCHEVA, Sanofi-Aventis, BULGARIA.

M. POLASEK, Faculty of Pharmacy, Charles University, CZECH REPUBLIC.

U. MADSEN and B. FJALLAND, Faculty of Pharmaceutical Sciences, University of Copenhagen; M. BRANDL, Faculty of Science, University of Southern Denmark; M. RINGKJØBING-ELEMA, EIPG / the Association of Danish Industrial Pharmacists, DENMARK.

P. VESKI and D. VOLMER, Department of Pharmacy, University of Tartu, ESTONIA.

J. HIRVONEN and A. JUPPO, University of Helsinki, Faculty of Pharmacy, FINLAND.

C. CAPDEVILLE-ATKINSON, Nancy University, FRANCE; A. MARCINCAL, Faculté de Pharmacie, Université de Lille 2; V. LACAMOIRE and I. BARON, Conseil National de l'Ordre des Pharmaciens, FRANCE.

R. SÜSS and R. SCHUBERT, University of Freiburg, GERMANY.

P. MACHERAS, E. MIKROS and D. M. REKKAS, School of Pharmacy, University of Athens; K. POULAS, School of Pharmacy, University of Patras, GREECE.

G. SOOS and P. DORO, Faculty of Pharmacy, University of Szeged, HUNGARY.
T. KRISTMUNDSDOTTIR and A. B. ALMARSDOTTIR, Faculty of Pharmaceutical Sciences, University of Iceland, ICELAND.

J. STRAWBRIDGE and P. GALLAGHER, Royal College of Surgeons in Ireland, Dublin; L. HORGAN, Pharmaceutical Society of Ireland, PSI - The Pharmacy Regulator, IRELAND.

C. ROSSI, and P. BLASI Faculty of Pharmacy, University of Perugia, ITALY.

R. MUCENIECE, Faculty of Medicine of University of Latvia; B. MAURINA, Faculty of Pharmacy; I. SAPROVSKA, Latvian Branch, European Industrial Pharmacists' Group (EIPG), LATVIA.

V. BRIEDIS and M. SAPRAGONIENE, Lithuanian University of Health Sciences, LITHUANIA.

L. M. AZZOPARDI and A. S. INGLOTT, University of Malta, Department of Pharmacy, MALTA.

T. SCHALEKAMP, Utrecht University, Faculty of Science, Department of Pharmaceutical Sciences; H. J. HAISMA, University of Groningen, School of Life Sciences, Pharmacy and Pharmaceutical Sciences, THE NETHERLANDS.

K. M. ULSHAGEN, P. H. TUSVIK, L. TRELNES, Farmasøytisk Institutt, NORWAY.

S. POLAK and R. JACHOWICZ, Faculty of Pharmacy with Division of Medicinal Analysis, Jagiellonian University Medical College, POLAND.

J. A. G. MORAIS and A.M. CAVACO, Faculdade de Farmácia Universidade de Lisboa, PORTUGAL.

C. MIRCIOIU and C. RAIS, Faculty of Pharmacy, University of Medicine and Pharmacy "Carol Davila", ROMANIA.

J. KYSELOVIČ and M. REMKO, Faculty of Pharmacy, Comenius University, Odbojarov 10, Bratislava, 83232, SLOVAKIA

B. BOZIC and S. GOBEC, University of Ljubljana, Faculty of Pharmacy, SLOVENIA.

B. DEL CASTILLO-GARCIA, Facultad de Farmacia, Universidad Complutense de Madrid; L. RECALDE and A. SANCHEZ POZO, Facultad de Farmacia, Universidad de Granada, SPAIN.

R. HANSSON and E. BJÖRK, Faculty of Pharmacy, Uppsala University; G. TOBIN, Sahlgrenska Academy, SWEDEN.

F. HINCAL and L. O. DEMIREZER, Hacettepe University Faculty of Pharmacy, Department of Pharmaceutical Toxicology, TURKEY.

K. A WILSON, Aston Pharmacy School, Aston Triangle; G.B.LOCKWOOD, University of Manchester, School of Pharmacy \& Pharmaceutical Sciences., UNITED KINGDOM

J. CHAVE, General Secretary, PGEU, Pharmaceutical Group of the European Union.

J. NICHOLSON, General Secretary; EIPG, European Industrial Pharmacists Group.

R. FRONTINI, President; EAHP, European Association of Hospital Pharmacists.

The President, EPSA, European Pharmaceutical Students' Association. 


\section{ANNEX 1. Directive 2005/36/EC of the European Parliament and of the Council of the 7th September 2005 on the recognition of professional qualifications (Official Journal of the European Union, 30/9/2005, L255/22)}

\section{Section 7 Pharmacist}

Article 44 Training as a pharmacist

1. Admission to a course of training as a pharmacist shall be contingent upon possession of a diploma or certificate giving access, in a Member State, to the studies in question, at universities or higher institutes of a level recognised as equivalent.

2. Evidence of formal qualifications as a pharmacist shall attest to training of at least five years' duration, including at least:

(a) four years of full-time theoretical and practical training at a university or at a higher institute of a level recognised as equivalent, or under the supervision of a university;

(b) six-month traineeship in a pharmacy which is open to the public or in a hospital, under the supervision of that hospital's pharmaceutical department.

That training cycle shall include at least the programme described in Annex $\mathrm{V}$, point 5.6.1. The contents listed in Annex $\mathrm{V}$, point 5.6.1 may be amended in accordance with the procedure referred to in Article $58(2)$ with a view to adapting them to scientific and technical progress. Such updates must not entail, for any Member State, any amendment of existing legislative principles relating to the structure of professions as regards training and the conditions of access by natural persons.

3. Training for pharmacists shall provide an assurance that the person concerned has acquired the following knowledge and skills:

(a) adequate knowledge of medicines and the substances used in the manufacture of medicines;

(b) adequate knowledge of pharmaceutical technology and the physical, chemical, biological and microbiological testing of medicinal products;

(c) adequate knowledge of the metabolism and the effects of medicinal products and of the action of toxic substances, and of the use of medicinal products;

(d) adequate knowledge to evaluate scientific data concerning medicines in order to be able to supply appropriate information on the basis of this knowledge;

(e) adequate knowledge of the legal and other requirements associated with the pursuit of pharmacy.

Article 45 Pursuit of the professional activities of a pharmacist

1. For the purposes of this Directive, the activities of a pharmacist are those, access to which and pursuit of which are contingent, in one or more Member States, upon professional qualifications and which are open to holders of evidence of formal qualifications of the types listed in Annex $\mathrm{V}$, point 5.6.2.

2. The Member States shall ensure that the holders of evidence of formal qualifications in pharmacy at university level or a level deemed to be equivalent, which satisfies the provisions of Article 44, are able to gain access to and pursue at least the following activities, subject to the requirement, where appropriate, of supplementary professional experience:

(a) preparation of the pharmaceutical form of medicinal products;

(b) manufacture and testing of medicinal products;

(c) testing of medicinal products in a laboratory for the testing of medicinal products;

(d) storage, preservation and distribution of medicinal products at the wholesale stage;

(e) preparation, testing, storage and supply of medicinal products in pharmacies open to the public;

(f) preparation, testing, storage and dispensing of medicinal products in hospitals;

(g) provision of information and advice on medicinal products.

3. If a Member State makes access to or pursuit of one of the activities of a pharmacist contingent upon supplementary professional experience, in addition to possession of evidence of formal qualifications referred to in Annex $V$, point 5.6.2, that Member State shall recognise as sufficient proof in this regard a certificate issued by the competent authorities in the home Member State stating that the person concerned has been engaged in those activities in the home Member State for a similar period.

4. The recognition referred to in paragraph 3 shall not apply with regard to the two-year period of professional experience required by the Grand Duchy of Luxembourg for the grant of a State public pharmacy concession.

5. If, on 16 September 1985, a Member State had a competitive examination in place designed to select from among the holders referred to in paragraph 2, those who are to be authorised to become owners of new pharmacies whose creation has been decided on as part of a national system of geographical division, that Member State may, by way of derogation from paragraph 1, proceed with that examination and require nationals of Member States who possess evidence of formal qualifications as a pharmacist referred to in Annex $\mathrm{V}$, point 5.6 .2 or who benefit from the provisions of Article 23 to take part in it.

Annex V.6. PHARMACIST

5.6.1. Course of training for pharmacists

- Plant and animal biology

- Physics

- General and inorganic chemistry

- Organic chemistry 
- Analytical chemistry

- Pharmaceutical chemistry, including analysis of medicinal products

- General and applied biochemistry (medical)

- Anatomy and physiology; medical terminology

- Microbiology

- Pharmacology and pharmacotherapy

- Pharmaceutical technology

- Toxicology

- Pharmacognosy

- Legislation and, where appropriate, professional ethics.

The balance between theoretical and practical training shall, in respect of each subject, give sufficient importance to theory to maintain the university character of the training.

See: http://eur-lex.europa.eu/LexUriServ/LexUriServ.do?uri=OJ:L:2005:255:0022:0142:en:PDF

\section{Annex 2. Bologna Declaration (1999).}

The Bologna declaration has the following six actions:

1. Adoption of a system of easily readable and comparable degrees, also through the implementation of the Diploma Supplement, in order to promote European citizens employability and the international competitiveness of the European higher education system.

2. Adoption of a system essentially based on two main cycles, undergraduate and graduate. Access to the second cycle shall require successful completion of first cycle studies, lasting a minimum of three years. The degree awarded after the first cycle shall also be relevant to the European labour market as an appropriate level of qualification. The second cycle should lead to the master and/or doctorate degree as in many European countries.

3. Establishment of a system of credits - such as in the ECTS system - as a proper means of promoting the most widespread student mobility. Credits could also be acquired in non-higher education contexts, including lifelong learning, provided they are recognised by receiving Universities concerned.

4. Promotion of mobility by overcoming obstacles to the effective exercise of free movement with particular attention to:

a. for students, access to study and training opportunities and to related services

b. for teachers, researchers and administrative staff, recognition and valorisation of periods spent in a European context researching, teaching and training, without prejudicing their statutory rights.

5. Promotion of European co-operation in quality assurance with a view to developing comparable criteria and methodologies.

6. Promotion of the necessary European dimensions in higher education, particularly with regards to curricular development, inter-institutional co-operation, mobility schemes and integrated programmes of study, training and research

The Bologna system as modified in Berlin (2003) is now a three tiers system. The process involves the division of a university diploma into three levels: $B, M$ and $D$ (Bachelor, Master and Doctorate) as follows:

1. Undergraduate/First cycle - Bachelor: three years after the end of secondary education (in schools); acquisition of generic skills and skills related to incorporation into the workforce. The bachelor degree is validated with 180 ECTS units.

2. Postgraduate

a. Second cycle - Master: five years after secondary education; acquisition of skills related to incorporation into the workforce and introduction of research aspects. The master degree is validated with 120 ECTSs.

b. Third cycle - Doctorate: no official timescale (generally eight years following secondary education); acquisition of skills, knowledge and experience for a career in research. The number of ECTSs for a doctorate has not yet been defined.

Within this system each university proposes its own education and training possibly in coordination with other institutions in the region. Courses are organised at the bachelor and master level into fields grouping several subjects and subject areas. The organisation of courses is flexible with obligatory, optional or open courses. The acceptance onto a given course depends on the student's knowledge and capabilities and also on the adaptation of his or her previous education and training to the proposed course. Employability of the graduates at each of the 3 levels is a top priority in the adoption of the reform of a given curriculum into a BMD system.

See:

http://www.ond.vlaanderen.be/hogeronderwijs/bologna/

http://www.eua.be/bologna-universities-reform/

http://ec.europa.eu/education/higher-education/doc1290 en.htm 
European Higher Education Area (EHEA)

"In the European Higher Education Area, qualifications frameworks are found at two levels. An overarching framework has been adopted for the EHEA in 2005; and by 2010, all member countries will develop national qualifications frameworks that are compatible with this overarching framework." From the official website of the Bologna process 2007-2009 at: www.ond.vlaanderen.be/hogeronderwijs/bologna/qf/qf.asp 